\title{
X-Linked Centronuclear Myopathy
}

National Cancer Institute

\section{Source}

National Cancer Institute. X-Linked Centronuclear Myopathy. NCI Thesaurus. Code C118781.

An X-linked recessive inherited disorder caused by mutations in the MTM1 gene. Primarily it affects males. Female carriers are usually asymptomatic. It is characterized by skeletal muscle weakness and hypotonia. The muscle weakness ranges from mild to severe. Newborns with severe X-linked centronuclear myopathy develop respiratory distress which may lead to respiratory failure requiring constant ventilator assistance. Patients with mild X-linked centronuclear myopathy usually require ventilator support during the newborn period only. 